\title{
Chemical and biological progress of Podocarpus nagi
}

\author{
Yang Yang ${ }^{1,2}$, Jianping Yong ${ }^{1 *}$ and Canzhong $\mathrm{Lu}^{1,3 *}$ \\ ${ }^{1}$ Xiamen Institute of Rare-earth Materials, Haixi Institute, Chinese Academy of Sciences, Xiamen, 361021, China \\ ${ }^{2}$ Shanghai Tech University, Shanghai, 201210, China \\ ${ }^{3}$ Fujian Institute of Research on the Structure of Matter, Haixi Institute, Chinese Academy of Sciences, Fuzhou, 350002, China
}

\begin{abstract}
Podocarpus nagi is a tree belonging to the family of Podocarpaceae, which has ever been used for treatment of trauma, stop-bleeding, fractures, knife wounds, gunshot wounds, body odor, eye diseases, colds and rheumatoid arthritis in clinic. Some compounds have been isolated and their biological activities were also evaluated. This review briefly describes the progress of the chemical components and biological activities of podocarpus nagi, for providing a reference for the researchers.
\end{abstract}

\section{Introduction}

Podocarpus nagi (named Zhubai in Chinese) is a tree belonging to the family of Podocarpaceae, widely distributed in the South District of the Yangtse River, such as Jiangxi, Zhejiang, Fujian, Hunan, Guangxi and Guangdong, etc. In Nanping, Sanming and Zhangzhou of Fujian Province, there are small-scaled natural communities or artificial enclosure planting of Podocarpus nagi, which is a native tree species of local place. The branches of Podocarpus nagi are excellent materials for building, furniture and craft. The oil content of its seeds is higher and can be used for edible after being refined or directly used industrially [1]. Some compounds and biological activities have been studied. In this mini-review, we briefly describe the progress of the chemical components and biological activities of podocarpus nagi.

\section{Chemical components of Podocarpus nagi}

According to the reported literatures, there are many active components in the branches, leaves and seeds of Podocarpus nagi, which include volatile oils, terpenoids, cypress lactones, flavonoids, lignin and cyclic peptides. The main components of essential oil in the leaves of Podocarpus nagi are elemene, cadinene, $\beta$-palindolene, pinene and caryophyllene.

\section{Volatile oils}

Yang Rongbin et al. [2] extracted the volatile oil from the leaves of Podocarpus nagi grown in Guangzhou, Guangdong Province, and identified the components and contents by GC-MS. The results showed that the main components are (-)- $\alpha$-pinene (5.591\%), $\beta$-elemene (9.577\%), (-)- $\alpha$-elemene (7.102\%), caryophyllene (2.235\%), $\alpha$-cadinene (10.04\%), 4-isopropenylidene-1-vinylmenthene (53.82\%); He Daohang et al. [3] extracted volatile oil from the leaves of Podocarpus nagi grown in Zengcheng district of Guangdong Province, and identified the components and contents by GC-MS. The results showed that the main components are (-)-spathulenol (3.15\%), $\alpha$-pinene $(8.67 \%)$, (-)- $\beta$-elemene (2.68\%), $\beta$-caryophyllene (3.97\%), germacrene $(21.56 \%)$, $\beta$-cadinene $(2.02 \%), \quad(+)$-ledene $(2.11 \%), \quad 4$-isopropenylidene-1vinylmenthene (45.13\%); HuWenjie et al. [4] extracted volatile oil from the leaves of Podocarpus nagi grown in Jiangxi province, and identified the components and contents by GC-MS. The results showed that the main components are spathulenol, cadinenol, $\alpha$-cadinol, $\alpha$-pinene, 3 -thujene, $\beta$-elemene, $\gamma$-elemene, $\beta$-cadinene, aromadendrene, germacrene $\mathrm{D}, \quad \gamma$-muurolene, $\alpha$-caryophyllene, $\delta$-cadinene, $\beta$-caryophyllene, $\beta$-cadinene, viridiflorene. The authors also extracted the volatile oil from the branches of Podocarpus nagi and identified the components and contents by GC-MS. The results showed that the main components are 1-hepten-3-ol, $\alpha$-pinene, 3 -thujene, caryophyllene, $\beta$-cadinene, $\alpha$-caryophyllene, germacrene $B$, eremophilene, $\alpha$-amorphene, $\gamma$-cadinene, $\delta$-cadinene. By comparison the results reported by Yang Rongbing and He Daohang [2,3], there are much difference between the components and contents of volatile oil, the reasons can be due to the Podocarpus nagi growing the different places; Liao Zeyong et al. [5] extracted volatile oil from the peel and nutshell of Podocarpus nagi fruits and identified the components and contents by GC-MS, respectively. The results showed that the volatile oil is very low in peel, while the volatile oil is higher in nutshell.

From the results reported above, we can know that the main components of the volatile oil are terpenes.

\section{Flavonoids}

It was reported that the seeds of Podocarpus nagi contained biflavonoids: sciadopitysin and amentoflavone $-4,4$ 4', 7, 7'-tetramethylether [6]. Wang Qiuxiang et al. [7] isolated the amentoflavone, bilobetin, podocarpusflavone A, quercetin, (-)-catechin from the leaves of Podocarpus nagi. Xu Yaming et al. [8] isolated isoginkgetin from the leaves of Podocarpus nagi. The structures of flavonoids listed in figure 1.

${ }^{\star}$ Correspondence to: Jianping Yong, Xiamen Institute of Rare-earth Materials, Haixi Institute, Chinese Academy of Sciences, Xiamen, 361021, China, Tel: +86591-63173162; E-mail: jpyong@fjirsm.ac.cn

Canzhong Lu, Fujian Institute of Research on the Structure of Matter, Haixi Institute, Chinese Academy of Sciences, Fuzhou, 350002, China, Tel: +86-59183705794; E-mail: czlu@fjirsm.ac.cn

Key words: Podocarpus nagi, chemical components, biological activities

Received: September 10, 2018; Accepted: September 28, 2018; Published: October 10, 2018 
<smiles>COc1ccc(-c2cc(=O)c3c(O)cc(O)c(-c4cc(-c5cc(=O)c6c(O)cc(OC)cc6o5)ccc4OC)c3o2)cc1</smiles><smiles>O=c1cc(-c2ccc(O)c(-c3c(O)cc(O)c4c(=O)cc(-c5ccc(-c6ccc(O)cc6)cc5)oc34)c2)oc2cc(O)cc(O)c12</smiles><smiles>COc1ccc(-c2ccc(C3=CC(=O)C4=C(O)C=C(O)C(=C3O)c3cc5c(c(c3)=CC=C4O)=CC(=O)c3c(O)cc(O)cc3O5)cc2)cc1</smiles><smiles>COc1ccc(-c2cc(=O)c3c(O)cc(OC)c(-c4cc(OC)ccc4OC)c3o2)cc1</smiles>

Amentoflavone -4', 4', 7, 7'-tetramethylether<smiles>COc1ccc(-c2cc(=O)c3c(O)cc(O)cc3o2)cc1-c1c(O)cc(O)c2c(=O)cc(-c3ccc(-c4ccc(O)cc4)cc3)oc12</smiles><smiles>O=c1cc(-c2ccc(O)c(O)c2)oc2cc(O)cc(O)c12</smiles>

Quercetin<smiles>Oc1cc(O)c2c(c1)O[C@H](c1ccc(O)c(O)c1)[C@H](O)C2</smiles>

Figure 1. Representative structures of flavonoids isolated from Podocarpus nagi

\section{Steroids}

Wang Qiuxiang et al. [7] obtained 5 $5,6 \beta$-sitosterol from the leaves of Podocarpus nagi, which widely exists in many kinds of plant.

\section{Sugar and glycosides}

It was reported that the seeds of Podocarpus nagi contain polysaccharide compounds such as nagilactone A-1- $\beta$-D-glucoside, ethyl- $\beta$-D-glucopyranoside, nagilactone glycoside $A$ and sucrose $[6,9]$.

\section{Lactone compounds}

It was reported $[6,7,9]$ that the seeds of Podocarpus nagi contains nagilactone $\mathrm{A}, \mathrm{B}, \mathrm{C}, 15$-hydroxynagilactone $\mathrm{D}, 15$-methoxy-carbonylnagilctone

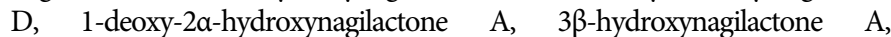
1-deoxy-2 $\beta, 3 \beta$-epoxynagilactone A. Podocarpus nagi stem bark contains 16-hydroxypodolide, 2,3-dihydro-16-hydroxypodolide, $2 \beta, 3 \beta$-epoxypodolide, 2,3-dihvdropodolide, 2,3-dehydro-l6-hydroxynagilactone $\mathrm{F}$, nagilactone I, 16-hydroxynagilactone E , 2a-hydroxyagilactone F, nagilactone E, 1-deoxy-2, 3-dehydronagilactone A, 1-deoxynagilactone A, 2,3-dehydronagilactone A, stem bark contains nagilactone C,D,I,J, 16-hydroxynagilactone E. The structures of representative nagilactones showed in figure 2 .

\section{Other components isolated from Podocarpus nagi}

Wang Qiuxiang et al. [7] isolated the prinsepiol from the leaves of Podocarpus nagi. According to the literatures reported, there are organic acids in the oil of the seeds of Podocarpus nagi, the nutmeg acid, palmitic acid, stearic acid, oleic acid, 9,12-linoleic acid, paullinic acid, eicosadienoic acid, carbonium are included [8,10]. We also extracted the oil of the seeds of Podocarpus nagi planted in Yangli town of Fujian province and analyzed its components, and palmitic acid, palmitic acid, octanoic acid, stearic acid, oleic acid, linoleic acid, peanut acid, arachidonic acid, $\alpha$-linolenic acid, arachidonic acid, behenicacid, lignoceric acid are detected.

\section{Biological activities}

It was reported that the leaves and bark of Podocarpus nagi can emit the odor similar to clove, which can repel the mosquitoes. In addition, as a kind of traditional Chinese herbal medicine, Podocarpus nagi exhibits hemostasis, bone setting and detumescence. As a kind of folk medicine of Yao nationality, Podocarpus nagi can also be used to treat trauma, stop-bleeding, fractures, knife wounds, gunshot wounds, body odor, eye diseases and colds, etc. The fresh barks or roots of Podocarpus nagi were also used to treat the rheumatoid arthritis $[5,6,11]$. 


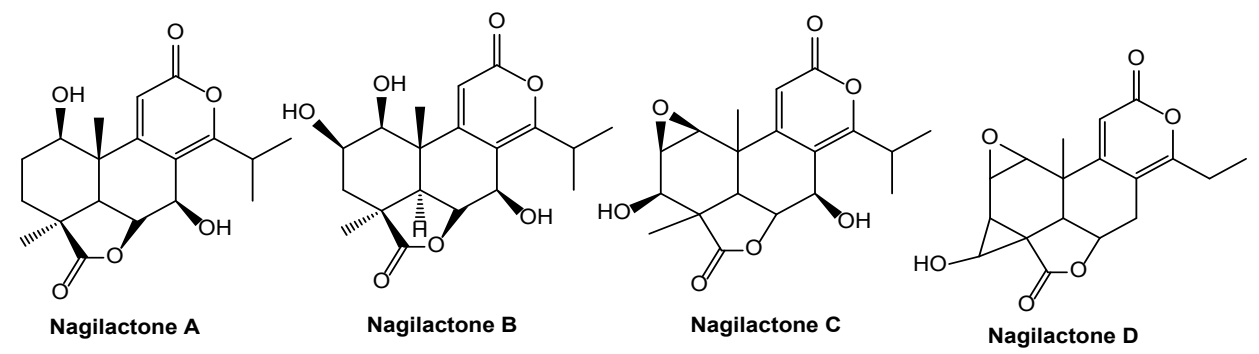

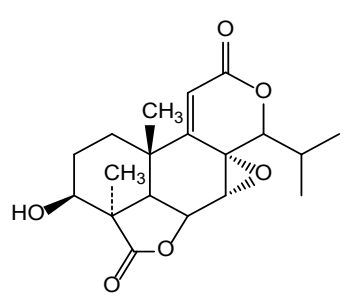

Nagilactone E

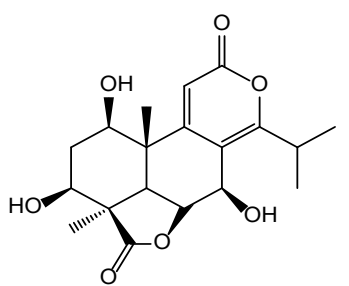

3-beta-hydroxynagilactone A

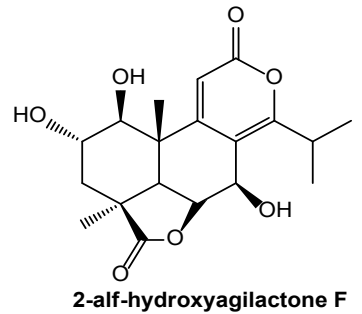

2-alf-hydroxyagilactone $F$<smiles>CC(C)c1oc(=O)cc2c1[C@H](O)[C@H]1OC(=O)[C@@]3(C)C=C[C@H](O)[C@@]2(C)C13</smiles><smiles>CC(C)c1oc(=O)cc2c1[C@H](O)[C@H]1OC(=O)[C@]3(C)C4OC4C[C@]2(C)C13</smiles>

1-deoxy-2beta,3beta-epoxynagilactone $A$<smiles>CC(CO)c1oc(=O)cc2c1[C@H](O)[C@H]1OC(=O)[C@@]3(C)C=C[C@H](O)[C@@]2(C)[C@H]13</smiles>

2,3-dehydro-16-hydroxynagilactone $F$

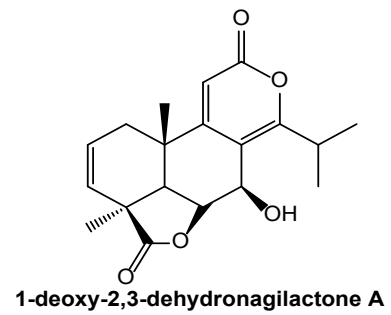<smiles>CC(C)c1oc(=O)cc2c1[C@H](O)[C@H]1OC(=O)[C@@]3(C)C=CC[C@](C)(C23)[C@@H]1C(=O)O</smiles><smiles>CC(C)c1oc(=O)cc2c1[C@H](O)C1OC(=O)[C@]3(C)C[C@H](C)C[C@]21C3</smiles>

1-deoxy-2alfa-hydroxynagilactone $A$<smiles></smiles>

16-hydroxynagilactone $\mathrm{E}$

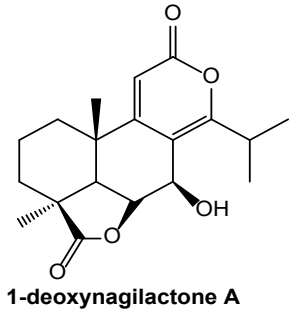

Figure 2. The structures of representative nagilactones

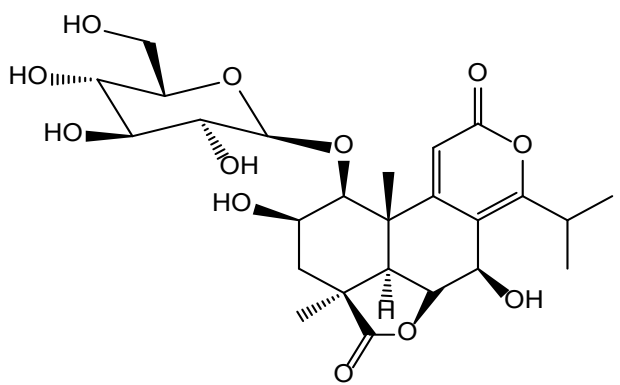

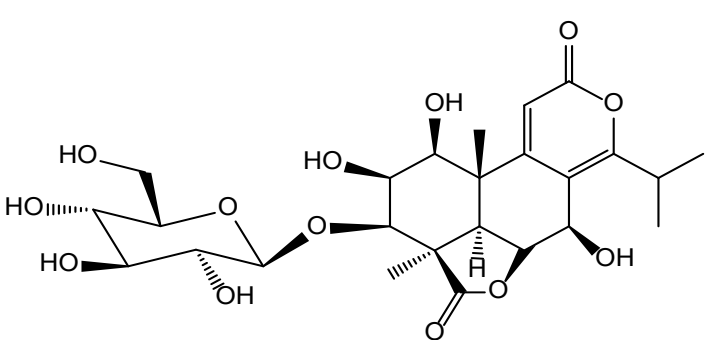

2

Figure 3. Podolactones isolated from podocarpus nagi with anti-inflammatory activity 


\section{Anticancer activity}

$\mathrm{Xu}$ Yaming et al. [7] reported that ngilactone A, 1-deoxy-2 $\beta, 3 \beta$ epoxynagilactone $A$ and 1-deoxy-2 $\alpha$-hy-droxynagilactone towards the leukemia, the results showed that these compounds exhibited cytotoxicity against $\mathrm{P}_{338}$ cell lines, and the inhibitions of these three compounds against $\mathrm{P}_{388}$ cell lines are $73,88.5$ and $97.4 \%$ respectively at the concentration of $10 \mathrm{ug} / \mathrm{mL}$. While the inhibition of ngilactone B towards $\mathrm{P}_{388}$ cell lines is $98.6 \%$ [9]. Lee et al. [12] reported that amentoflavone exhibited higher inhibition to phospholipase C. Liao Zeyong et al. studied the volatile oil from the peel and shell of Podocarpus nagi fruit towards nasopharyngeal carcinoma line CNE. The results showed that the inhibitions of volatile oil from the pericarp towards nasopharyngeal carcinoma line CNE are $(22.62 \pm 0.54) \%$, $(43.02 \pm 1.27) \%,(52.55 \pm 2.83) \%,(73.24 \pm 1.79) \%,(84.18 \pm 3.37) \%$ at the concentrations of $20,40,80,100,120 \mathrm{ug} / \mathrm{mL}$ respectively, while the inhibitions of volatile oil from shell towards nasopharyngeal carcinoma line CNE are $(18.37 \pm 1.13) \%$, (23.74 \pm 0.52$) \%$, $(38.55 \pm 1.04) \%$, (42.96 $\pm 2.15) \%,(68.14 \pm 2.06) \%$ at the concentrations of $20,40,80,100,120$ $\mu \mathrm{g} / \mathrm{mL}$ respectively.

\section{Anti-bacterial activity}

Kubo tested the $2 \alpha$-hydroxynagilactone $\mathrm{F}$ against saccharomyces beer yeast and the result showed that it exhibited stronger inhibitory activity against saccharomyces beer yeast and its MIC was $800 \mu \mathrm{g} / \mathrm{ml}$. Nagilactone C, nagilactone D, nagilactone E also exhibited inhibitory effects on fungi. Tartalol exhibited stronger inhibitory activity against staphylococcus aureus, while tartalol and totaradiol exhibited peculiar inhibitory activity against Gram-positive bacteria, and norditerpenoid dilactone showed peculiar activity against saccharomyces cerevisiae, blastomyces albicans and pityrosporum (Malassezia) ovale [13-18].

\section{Antiviral and other activities}

Matsuki et al reported that bilobetin exhibited potent antiviral activity against Epstein-Barr virus, and also stronger against carcinogen than that of vitamin A acid [19]. Feng Zheling et al. isolated some podolactones from Podocarpus nagi and evaluated their anti-inflammatory effect. The results showed that compounds 1 and 2 (Figure 3) significantly inhibited Nitric Oxide (NO) production on LPSstimulated RAW264.7 macrophages, with $\mathrm{IC}_{50}$ values of $0.18 \pm 0.04$ and $0.53 \pm 0.03 \mu \mathrm{M}$, respectively. Compound 1 suppressed the expression of inducible NO Synthase (iNOS) in a concentration-dependent manner, mediating through inhibiting nuclear factor $-\kappa \mathrm{B}(\mathrm{NF}-\kappa \mathrm{B})$ activity. This is the first report regarding the anti-inflammatory effect of podolactones, which could be potential anti-inflammatory agents [20]. Wang Yiping et al. [21] reported that nagilactone B can suppress atherosclerosis in apoE-deficient mice via enhancing apolipoprotein A-I and HDLmediated cholesterol efflux. Berger et al. [22] reported that Podocarpus nagi methyl esters could reduce skin surfaces inflammatory processes and reduce downstream inflammatory products: such as PGE2 and leukotrienes. It could have potential use in treating clinical skin disorders.

Through reviewing the progress of the chemical components and biological activities of podocarpus nagi, we found that only some simple studies have been carried out. These years, our research group carried out the drug design, synthesis, isolation of the plant medicines and their biological evaluation, and we have obtained remarkable results [2330]. Podocarpus nagi is a kind of native tree species in Fujian province, and there is a large-scaled artificial enclosure planting in Yangli town of Fujian province. Because Podocarpus Nagi is rich in sciadopitysin, amentoflavone, and bilobetin with good biological activity, including bone protection, stop-bleeding, treatment of trauma, fractures, knife wounds, gunshot wounds, body odor, eye diseases, colds and rheumatoid arthritis. Thus, our research group takes the lead to carry out the isolation and biological evaluation of podocarpus nagi planted in Fujian province.

\section{Acknowledgements}

This work was financially supported by the National Natural Science Foundation of China (21875252) and the project of The Plan of Xiamen Science and Technology (3502ZCQ20171000).

\section{References}

1. Chinese flora editorial board of chinese academy of sciences (1987) Flora of China Beijing: Science Press 7: 404-405.

2. Yang RB, Yuan XJ, Du HG (2008) Analysis of volatile oil in Podocarpus nagi leaves by GC-MS. Asia-Pasific Traditional Medicine 4: 51-52.

3. He DH, Pang Y, Ren SX, Li GH, Song SY (2005) Chemical constituents of volatile oil from podocarpus fleuryi hickel. Chemistry and Industry of Forest Products 25: 119 121

4. Hu WJ, Yang YH, Pi XT (2014) Analysis and comparison of the constituents of volatile oil from the leaves and twigs of podocarpus nagi. Journal of West China Forestry Science 43:135-138.

5. Liao ZY, Wei W (2015) Studies on volatile constituents and their anti-tumor activities from the peel and shell of podocarpus nagi fruits. Herald of Medicine 34: 609-612.

6. State Administration of Traditional Chinese Medicine Editorial Board (1999) Zhong Hua Ben Cao. Shanghai: Shanghai Scientific \& Technical Publishers. 813 -817.

7. Xu YM, Fang SD, He QM (1990) The chemical constituents from podocarpus fleuryi hickel. Acta Botanica Sinica 32: 302-306.

8. Xu YM, Fang SD (1989) Chemical Composition of Podocarpaceae. Anti-Tumor Chemical Composition in Podocarpus nagi. Acta Chimica Sinica 47: 1080.

9. Xu YM, Fang SD, He QM (1991) The structure of a new biflavone from podocarpus fleuryi. Acta Botanica Sinica 33: 162-163.

10. Dai B (2009) Chinese modern Yao medicine. Nanning: Guangxi science and Technology Publishers. 257-259.

11. Lee HS, Oh WK, Kim BY, Ahn SC, Kang DO, et al. (1996) Inhibition of phospholipase c gamma 1 activity by amentoflavone isolated from selaginella tamariscina. Planta Med 62: 293 -296. [Crossref]

12. Kubo I, et al. (1991) Two nor-diterpenedilactones from podocarpus nagi Phytochemistry, 30: 1964-1965.

13. Kubo I, Ying BP. (1991) A bisnorditerpenedilactone from Podocarpus nagi. Phytochemistry 30: 3476-3477.

14. Kubo I, Himejima M, Ying BP (1991) An antifungal norditerpene dilactone from Podocarpus nagi. Phytochemistry 30: 1467-1469.

15. Kubo I, Muroi H, Himejima M (1992) Antibacterial activity of totarol and its potentiation. J Nat Prod 55: 1436-1440. [Crossref]

16. Ying B P, Kubo I. (1993) Norditerpene dilactones from Podocarpus nagi. Phytochemistry 34: 1107-1110.

17. Xuan LJ, Xu YM, Fang SD (1995) Three diterpene dilactone glycosides from Podocarpus nagi. Phytochemistry 39: 1143-1145. [Crossref]

18. Matsuki. (1990) Study on Inhibition of EB Virus by Active ingredient in Ginkgo Leaves. International Journal of Traditional Chinese Medicine, 12: 58

19. Feng ZL, Zhang T, Liu JX, Chen XP, et al. (2018) New podolactones from the seeds of Podocarpus nagi and their anti-inflammatory effect. J Nat Med. [Crossref]

20. Gui YZ, Yao S, Yan H, Hu L, Yu CY, et al. (2016) A novel small molecule liver X receptor transcriptional regulator, nagilactone $\mathrm{B}$, suppresses atherosclerosis in apoEdeficient mice. Cardiovasc Res 112: 502-514. [Crossref]

21. Berger A, Monnard I, Baur M, Charbonnet C, Safonova I, et al. (2002) Epidermal antiinflammatory properties of 5,11,14 20:3: Effects on mouse ear edema, PGE2 levels in cultured keratinocytes, and PPAR activation. Lipids Health Dis 1: 1-12. [Crossref] 
22. Yong JP, Lu CZ, Wu X (2015) Potential anticancer agents I. synthesis of isoxazolemoiety containing quinazoline derivatives and preliminarily in vitro anticancer activity. Anticancer agents Med Chem 15: 131-136. [Crossref]

23. Yong J, Lu C, Wu X (2015) Synthesis and Biological Evaluation of Quinazoline Derivatives as Potential Anticancer Agents (II). Anticancer Agents Med Chem 15: 1326-1332. [Crossref]

24. Yong JP, Lu CZ, Wu XY (2014) Synthesis of isoxazole moiety containing ferrocenederivatives and preliminarily in vitro anticancer activity. Med Chem Comm 5: 968-972.

25. Lu CZ, Yong JP (2012) Quinazoline derivatives and application thereof. PCT/ WO2013143319A1; U. S. patent: 9193718B2; EP 2752413B1; ZL201210526123.X.
26. Lu CZ, Yong JP (2012) Thieno [2,3-d] Pyrimidine derivatives, preparation method and use Thereo. PCT/WO2014043866A1; U. S patent: 9434741B2; EP 2835372B1; ZL201210349508.3.

27. Yong J, Lu C (2012) Ferrocene drivatives, preparation method and use thereof. U. S. patent:9738673B1.

28. Yong J P, Wu X Y, Lu C Z (2014) Chemical constitutes isolated from the fruits of Loniceramaackii (Rupr.) Maxim Chem Nat Compd 50: 765-766.

29. Yong J P, Lu C Z, Huang S J (2014) Chemical constitutes isolated from the flower and fruits of Loniceramaackii (Rupr.) Maxim Chem Nat Compd 50:945-947.

30. Yong JP, Lu C Z, Wu XY (2015) Chemical components isolated from the roots of Morinda officinalis. Chem Nat Compd 50: 548-549.

Copyright: $(02018$ Yang Y. This is an open-access article distributed under the terms of the Creative Commons Attribution License, which permits unrestricted use, distribution, and reproduction in any medium, provided the original author and source are credited. 